\section{Ny lærebok i psykiatri}

Kringlen E.

Psykiatri

9. utg. 634 s, tab, ill. Oslo: Gyldendal Akademisk, 2008. Pris NOK 545

ISBN 978-82-05-38785-0

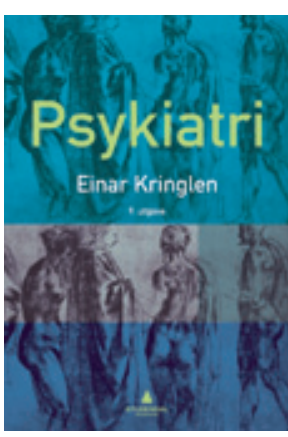

Einar Kringlen har udgivet niende udgave af Psykiatri. Målgruppen er alle med tilknytning til psykiatrien, medicinske studenter, læger, sundhedspersonale, administratorer og politikere. De 31 kapitler dækker

et bredt spektrum inden for psykiatrien. Bogen er velskrevet og lettilgængelig med hensyn til sprog og opbygning. En række illustrationer, tabeller og figurer, bidrager til at formidle budskaber klart og overskueligt.

Bogen indledes med et grundigt og farverigt kapitel om psykiatriens historie, som vel næppe kan betragtes som pensum for de studerende, men som bidrager til at give bogen dybde. Alle de kliniske kapitler indeholder malende vignetter, der på pædagogisk vis illustrerer sygdomstilfældene. For at udfylde funktionen som klassisk lærebog, kunne man ønske sig, at de diagnostiske kriterier indgik eksplicit i de kliniske kapitler, at differentialdiagnostik blev omtalt systematisk, og at der blev nævnt eller optrykt eksempler på skalaer til bedømmelse af sværhedsgrad af forskellige psykopatologiske fænomener. Evidensbaseret medicin omtales indledningsvist, og denne tilgang inddrages sporadisk senere i bogen. I forbindelse med de enkelte interventioner, der nævnes i de forskellige kapitler er der kun i beskeden grad overvejelser over hvilken grad af evidens, der er for den pågældende intervention, og det er ikke overbevisende at forfatterens personlige erfaringer, kasuistiske beretninger og mindre undersøgelser af ældre dato nævnes uden vægtning i flæng med omtalen af store randomiserede forsøg.

Kapitlerne om personlighedsforstyrrelser og misbrug skal fremhæves som særligt informationsmættede, klare og pædagogiske. Kapitlet om epidemiologi er velskrevet og interessant, men omhandler næsten udelukkende undersøgelse af forekomst af forskellige sygdomsmanifestationer, mens de muligheder for ætiologisk registerbaseret forskning, som ligger i den moderne epidemiologi knapt nok berøres. I kapitlet om forebyggelse kunne man ønske sig, at de forebyggelsesperspektiver, der tegner sig i den aktuelle ætiologiske forskning blev inddraget.

Det er imponerende, at en enkelt person kan overskue hele det psykiatriske felt og præsentere en sammenhængende og stort set opdateret fremstilling af alle områder indenfor psykiatrien. Ikke desto mindre ville bogen formentligt vinde i opdatering, overblik og klarhed ved at overgå til at være en antologi, således at professionelle med absolut spidskompetence blev forfattere til hver deres kapitler.

Bogen kan anbefales til medicinstuderende, alment praktiserende læger, læger under specialistuddannelse i psykiatri. Den er skrevet i et letlæseligt sprog, og fremstillingen er pædagogisk, og bogen kan dermed også anvendes af andre faggrupper, patienter og pårørende.

\section{Merete Nordentoft}

Psykiatrisk Center Bispebjerg

Det Sundhedsvidenskabelige Fakultet

Københavns Universitet

\section{Kort lærebok i psykiatri}

Aarre TF, Bugge P, Juklestad SI.

Psykiatri for helsefag

262 s, tab, ill. Bergen: Fagbokforlaget, 2009

Pris NOK 389

ISBN 978-82-7674-846-8

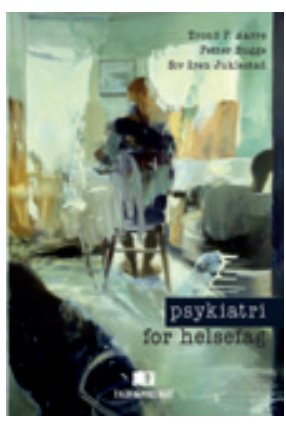

I forordet heter det at forfatterne synes at tidligere lærebøker tar for lett på behandlingsforskning og sykdomslære og at de har hatt ambisjoner om å bidra med oppdatert kunnskap på disse områder slik den forelå som-

meren 2007. De sier også at stoffet måtte komprimeres og at boken bør leses sammen med innføringer i psykiatrisk sykepleie og andre arbeidsmetoder i psykisk helsevern. På omslaget står det at boken er myntet på sykepleiestudenter og dem som tar videreutdanning i psykisk helsearbeid og at den er nyttig for medisinstudenter og allmennpraktiserende leger.

Kapitlene omhandler diagnostikk, behandling (psykoterapi, farmakoterapi og elektrokonvulsiv terapi), det som oppfattes som de viktigste diagnosegruppene: schizofreni og andre psykotiske lidelser, stemningslidelser, angstlidelser, personlighetsforstyrrelser, spiseforstyrrelser, hyperkinetiske forstyrrelser hos voksne, og videre kapitler om alderspsykiatri, rusmiddelmisbruk og psykiske lidelser, selvskading og selvmord, psykisk helsevernloven og et avsluttende kapittel om et sosialpsykiatrisk perspektiv. Forfatterne sier at de legger stor vekt på hva vi vet om effekten av behandling, og at utgangspunktet er at effektene bare kan bli påvist i kontrollerte studier. Mange slike relevante studier refereres også, men denne ambisiøse målsetting følges ikke opp overalt når forfatterne ikke er konsekvente og bl.a. fremmer egne helsepolitiske oppfatninger om det desentraliserte helsevesens fortreffelighet uten gode referanser.

Forfatterne forsøker å gi et realistisk bilde av alvoret ved det å ha en psykisk lidelse ved å dempe forventningene til prognosen. Etter min oppfatning er de imidlertid for pessimistiske når de generelt hevder at det er få som blir varig friske. I omtalen av vrangforestillingslidelse overses det faktum at dette i svært mange tilfeller er en forbigående tilstand, og at behandling hos langvarig rammede også kan gi effekt. Anoreksi omtales som vår mest dødelige psykiatriske lidelse, mens dette er en tilstand hvor prognosen etter behandling i vårt land kan være god - f.eks. ingen døde i undersøkelsespopulasjonen i Inger Halvorsens avhandling (1).

Det blir mye oppramsing av symptomer og forekomster, men det er vanskelig å unngå i en slik bok. Imidlertid hadde det vært en fordel om det konsekvent var brukt ett diagnostisk system, ikke noen steder DSM-IV og andre steder ICD-10. En del stigmatiserende uttrykk som «anorektikeren», «hos schizofrene» og fremstilling av perfeksjonisme som en psykisk lidelse skjemmer også. Det samme gjør utsagn som: «Sideventriklene i hjernen er større hos schizofrene enn hos friske.» Mange pasienter som på et gitt tidspunkt har symptomer som gjør at de oppfyller kriteriene for schizofreni i et vanlig benyttet diagnostisk system, har sideventrikler som ikke er større enn «hos friske».

I store deler av boken finnes det mye bra, presentert på et flytende og godt språk, men finishen mangler. Etter mitt syn er denne boken ikke bedre enn andre lærebøker for medisinstudenter og allmennpraktiserende leger. Det er likevel mulig den vil finne sin plass hos sykepleiestudenter og andre medarbeidere innen psykisk helsearbeid.

\section{Stein Opjordsmoen Itner}

Psykiatrisk divisjon

Oslo universitetssykehus, Ullevål

\section{Litteratur}

1. Halvorsen I. Outcome of anorexia nervosa in child hood and adolescence: intermediate to long-term follow-up of a county sample. Doktoravhandling. Oslo: Universitetet i Oslo, 2007. 